\title{
Study on Bovine Trypanosomosis and Tsetse Identification in South Ari Woreda of Southern Nation, Nationalities and People Regional State (SNNPRS)
}

\author{
Zerihune Teshome* \\ Woilta Zone Livestock Department of Livestock and Fishery Resource \\ Mulugeta Biamesh \\ Haramaya University Faculty of Veterinary Medicine
}

\begin{abstract}
The study was conducted from December 2009 to March 2010 in South Ari Woreda of SNNP Regional State to determine the prevalence of bovine trypanosomosis and to assess the apparent densities and distributions of tsetse flies. Blood samples were taken from a total of 384 indigenous cattle managed under small holder mixed crop livestock production. Blood Buffy coat dark ground phase contrast Microscopic technique was used for detection of the trypanosome parasites in the blood samples, NGU traps were used for tsetse fly survey and Packed cell volume (PCV) to determine the degree of anemia caused by trypanosomosis. The overall prevalence of $13.54 \%$ bovine trypanosomosis was recorded in the study area. The predominant species of trypanosome encountered during the study period were $T$. congolonce with relative prevalence of (63.5\%) followed by $T$. vivax (36.5\%) but there was no mixed infection observed. PCV evaluation showed that the mean PCV of parasitemic animals (25.5\%) was significantly lower than that of $(30.5 \%)$ aparasitemic animals indicating the importance of bovine trypanosomosis in causing anemia. Assessment of tsetse flies indicated that Glossina pallidipes is the major biological vector for bovine trypanosomosis in the study area with apparent density of $27.5 \mathrm{fly} /$ trap/day. Other biting flies (tabanids and stmoxys) were also collected indicating the possibility of mechanical transmission.
\end{abstract}

Keywords: Bovine, Trypanosomosis, Prevalence, Tsetse fly, apparent density, South Ari/S

DOI: $10.7176 / \mathrm{JBAH} / 10-20-04$

Publication date:October $31^{\text {st }} 2020$

\section{INTRODUCTION}

Ethiopia estimated livestock population is often said to the largest in Africa it is estimated to be over 150 million in 2007/2008. Excluding Afar and Somali Region there were approximately 47.5 million head cattle, 26.1 million sheep, 21.7 million Goats, 2.1 million Horse and mules, 5.6 million Donkeys, 1 million Camels and 39.6 million Poultry (CSA, 2009).

Trypanosomosis is a group of parasitic disease caused by unicellular parasite (trypanosome) found in the blood and other fluids of vertebrates including Livestock, wild life and people. Bovine trypanosomosis caused a significant loss in animal production and it greatly hampers human settlement in a considerable part of the word (Uilenberg, 1998).

Tsetse transmitted animal trypanosomosis is one of the major constraints to the socioeconomic development in Africa. Tsetse flies (Glossina spp.) infest approximately 10 million $\mathrm{km}^{2}$ of the continent affecting 38 countries which constitute about $37 \%$ of the continent considered that 7 million $\mathrm{km}^{2}$ of this area would otherwise be suitable for livestock or/and mixed agricultural development were it is not for trypanosomosis. These areas could theoretical support additional 140 Million cattle as well as equivalent number of sheep, Goat and relieve pressure on peripheral fragile areas (ILCA, 1988). About 30\% the 150 Million cattle in countries are affected by tsetse are exposed to the disease (Holmes, 1991).

In Ethiopia, trypanosomosis is one of the most important disease limiting livestock productivity and agricultural development. It can be transmitted between the hosts mainly by tsetse flies cyclically, by other biting flies mechanically and by other means of transmission (Awoke, 2000; Uilenberg, 1998). Trypanosomosis of cattle (locally known as "Gende") can be found in many provinces of Ethiopia where it has greatly hindered development. The most important trypanosome species affecting livestock in Ethiopia are Trypanosoma congolense, T.vivax and T. brucei in cattle, sheep and Goats, T. evansi in camels and T. equiperdem in horses (Getachew, 2005).

In 1962, the cattle survey in southern Ethiopia, by the livestock division, established the bovine trypanosomosis had become a major cattle disease in the Omo valley. It was stated that the problem of trypanosomosis is the main cause of decline in number of cattle and particularly drought oxen (Abebe and Jober, 1996).

Trypanosoma vivax, T. congolonse, T.brucei brucei and T. simiae are the four main species responsible for African trypanosome cases affecting virtually all domestic mammals T.vivax and T.congolense are the main pathogens of cattle. The four species are member of the saliverian group of trypanosomes and are transmitted 
cyclically via the Mouth parts of tsetse flies, hence the name saliverian trypanosomes. $T$. Vivax usually numerous in bovine blood and can be identified by its very fast movment in wet films, in stained smears it is a long slender with long free flagellum. T.congolonse is smaller, sluggish in wet films in stained smears; it is short and no free flagellum (Radostitis, 2007).

The Epidemiology of trypanosomosis depends on the distribution of the vectors, the virulence of the parasite and the response of the host of the three groups of Glossina, the savanah and the reverian are the most important vectors since they inhibit areas suitable for grazing and watering. Tsetse flies in Ethiopia are confined to the Southern and western regions between longitude $33^{\circ} \mathrm{E}$ and $38^{\circ} \mathrm{E}$ and latitude $5^{\circ} \mathrm{N}$ and $12^{\circ} \mathrm{N}$. They infest areas which together amount to $220,000 \mathrm{Km}^{2}$ tsetse infested areas Lie in the low lands and also in the river valley of Abay (Blue Nile), Baro, Akobo, Diddesa, Ghibe and Omo (Langridge, 1976).

The vector, tsetse fly, can be classified in the order dipteria (the two winged flies), family Glosindae, and within the genus, Glosina. There are about 23 species and 8 sub species of Glossina identified so far (Moloo, 1993; Leak, 1999). From Morphological point of view tsetse flies are elongated and robust of varies shades of brown ranging from yellowish to grayish to dark or blackish brown in color and about 6 to 16mm long excluding the proboscis. Males are smaller than the females (Itard, 1989).

The General distribution of tsetse flies; determined principally by climate and influenced by altitude, vegetation and the presence of suitable host animals has been known for a long time (Leak, 1999). Each of these factors may directly affect the birth, death or migration rates of the vector and thus the population size (Hay et al., 1996). The limit of distribution is closely correlated with the tropical savannah (summer rain) climate, which follows the $508 \mathrm{~mm}$ annual rain fall. Altitude influence tsetse distribution through its effect on climate, particularly temperature (Leak, 1999). In Ethiopia, 1600 M.a.s.l. was considered the upper altitudinal limit to tsetse distribution according to (Langridge, 1976). Subsequently however, G. Pallidipes was found at altitude up to 2200M (Tikubet and Gemech, 1984).

There is also a difference in host susceptibility to trypanosomes, which is best examplified by the small East African breeds of cattle such as N'dama and West Africa short horn. These animals are less susceptible to the disease than zebu or the Europian breeds and are commonly found in endemic areas of trypanosomosis. They are refered to as 'trypanotolerant' breeds (Morrison et al., 1981).

In the pathogenesis of infected tsetse inoculate metacyclic trypanosomes in to the skin of animals where the trypanosomes grow for few days and cause localized swelling (chancre). They enter the lymph nodes, then the blood stream, where they divided rapidly by binary fission in $T$. congolonse infection. The organisms attach to the endothilial cells and localize in capillaries and small blood vessels, T.brucei species and T.vivax invade tissue and cause damage in several organs. The Immune response is vigorous and immune complexes cause inflamation, which contributites to the signs and lesion of the disease Antibodies against the surface-coat glycoproteins kill the trypanosomes. However trypanosomes have multiple genes that code for different surface-coat glycoproteins that are not vulnerable to the immune response (Cynthia and Scott, 2005).

The diagnosis is important both in clinical medicine and epidemiological investigation. The disease shows a variety of clinical Manifestations, which are also common to other disease. The disease may run an acute, chronic or subclinical course and fever can be observed which can be intermittent due to the variation of parasitemia, and the animal survives, the disease become chronic and there is development of anemia and Emaciation (Blood et. al. 1989). Anemia, fever and loss of condition are important parameters; which are routinely used for the tentative diagnosis of trypanosomosis in areas where the disease is endemic and laboratory services are not available. However clinical signs of trypanosomosis are not pathogenic to the disease and diagnosis is safely attained by parasitalogical methods live dark ground phase contrast Buffy coat technique (Murray et al., 1977). Which can be used under field condition to detect the presence or absence of trypanosomes and trypanosome species are identified from thin or thick smears of positive samples (Uilenberg, 1998).

Treatment against trypanosomosis in order to be effective should be given early in the initial phase of fluctuating parasitemia. As no new drugs have been withdrawn because of resistance; treatment is now essential limited to two compounds, diminazine aceturate and homidium salts (either chloride or bromide) (Andrew et al., 1993; Afework et al., 2000; Tewolde et al., 2004).

Control is aimed at interrupting the cycle of development of the protozoan, either with in the Mammalian host or the insect vector. Control of trypanosomosis except for dourine can be based on: control of the parasite trypnosomes; control of vectors tsetse or biting flies; use of trypano tolerant animals and integrated approach combining other methods (Uilenberg, 1998). Vector control is the most reliable means of disease control since it removes the treat of trypanosomosis on a permanent basis. many vector control methods including woody vegetation clearance to remove tsetse shelter, and large scale application of insecticides by air and ground spraying and large wild life elimination could be applied, one of the latest methods of control is the sterile insects technique (SIT) involving continuous release of sterile insects among the indigenous insect population at rates sufficient to result in a reduction in biotic potential of the target population. The mating of released sterile male insects with indigenous fertile female insects cause infertility in the target population (SIT, 1996). 
Thus the objectives of this study are:

$>$ To study the prevalence of bovine trypanosomosis in south Ari

$>$ To assess the apparent density and distribution of tsetse and other biting flies in the study area

\section{MATERIALS AND METHOD}

\subsection{Study area}

The present study on the prevalence of bovine trypanosomosis and identification of tsetse was conducted in five selected peasant associations of the south Air woreda.

South Air is one of the south Omo zone woredas situated about $585 \mathrm{~km}$ from Hawasa and $767 \mathrm{~km}$ from south of Addis Ababa. It is located in the Great Rift Valley at $0^{0}-48^{0} \mathrm{~N}$ latitude and $33^{\circ}-36^{\circ} \mathrm{S}$ longitude. The altitude of the study area ranges from 1500-3418 m.a.s.l. South Air and its surrounding is characterized by subtropical weather with minimum and maximum Temperature ranging from $10.01^{\circ} \mathrm{C}-27.5^{\circ} \mathrm{C}$ and the mean annual rain fall is $600-1600 \mathrm{~mm}$. (South Air OWA).

The local human population is principally engaged in livestock crop (Mixed) farming system. Cattle, goats, sheep. Equine and poultry are often kept in the study PAs. South Ari has livestock population of 355,227 from this cattle, 99,168, sheep 64,807, Goat, 31,386, Equine, 12, 594 and poultry 147, 272. The major crops grown in south Air are corn, wheat, barley, navy beans, and coffee. Because of bordering with Mago National Park there are a number of wild animals living in the forests like hyena, cheetah, lion, zebra, warthog, large and small apes, antelopes and other wild animals which serve as host for tsetse and trypanosome reservoir (South Ari OWA).

\subsection{Study Population}

Cross- sectional study was conducted from December 2009 - March 2010 on 384 Indigenous cattle managed under small holder mixed crop-livestock farming system and semi pastoralist community. Local indigenous zebu cattle were considered in this study.

\subsection{Study design}

\subsubsection{Sampling method and sample size determination}

The sampling method applied in the present study was a simple random sampling; from the study population of 77 animals from each four peasant associations and 76 animals from remain one peasant association of south Ari. The sample size was calculated by using Thrustfield formula (Thrustfield, 2005) using 95\% CI and expected prevalence of $50 \%$

$$
\mathrm{N}=\frac{1.96^{2} \times \operatorname{Pexp}(1-\mathrm{Pexp})}{\mathrm{d}^{2}}
$$

Where:

$$
\begin{aligned}
& \mathrm{N}=\text { required sample size } \\
& \text { Pexp = Expected prevalence }=50 \% \\
& \mathrm{~d}=\text { Desired absolute precision }=0.05 \\
& \mathrm{CI}=\text { Confidense Interval }=95 \% \\
& \mathrm{~N}=\frac{1.96^{2} \times 0.5 \times(1-0.5)}{(0.05)^{2}} \\
& \mathrm{~N}=384
\end{aligned}
$$

\subsubsection{Data Management and analysis}

Data collected from vector fly and trypanosome infection survey entered into MS Excel Spreadsheet program to create database. Statistical analysis was employed with Stata $7.0 \mathrm{soft}$ ware for data management and analysis. The tested hypotheses were prevalence of trypanosomosis, PCV value the relation between tsetse aparent density and prevalence of trypanosomosis, the relation between PCV value and prevalence of trypanosomosis were tested. Kinds of descriptive statistics which were used are confidence Interval, Mean, and chi square methods

\subsection{Methodology}

\subsubsection{Parasitological Survey}

Blood samples were collected after properly restraining the animal and aseptically preparing the area around the veins. It was collected from the ear vein by using sterile blood lancet and capillary tubes. A pair of heparinized capillary tubes were filed with blood from animals to $3 / 4$ of their height and sealed at one end with crystal sealant. The capillary tubes were loaded on the Micro hematocrit centrifuge symmetrically and centrifuged at $1200 \mathrm{rpm}$ for 5 minutes (Murray et al., 1977). Packed cell volume (PCV) was determined using hematocrit reader (Woo, 1969). After the PVC was read, capillary tubes were Brocken $1 \mathrm{~mm}$ below the Buffy coat to include the red blood cells layer and the content were expressed on Microscopic slide and mixed and covered with a 22 X $22 \mathrm{~mm}$ cover slip ground Buffy coat technique (Murray et al., 1977) From positive samples thin blood smears were made fixed 
with methanol for 5 minutes and stained with Giemsa solution for 30 minutes and examined using oil immersion under X100 objective to detect the species of trypanosomes.

\subsubsection{Entomological Survey}

To assess the apparent densities, distribution and species of tsetse flies and other biting flies survey conducted. NGU traps baited with acetone and three-week old cow urine (Bright well et al., 1991) was used for assessing the fly density. Site selection was done to include suitable tsetse habitats live savannah area, rift valleys, live stock greathing areas and watering points and vicinity to assumed wild game reserve areas.

In all study sites a total of 12 NGU traps, six traps in Bytsemal Neri river and the other six in kure passure land were deployed early in the morning and maintained for 24 hours perceive flies the tsetse density. Traps were sited preferably in shade with good visibility and at suitable intervals depending on the ecology of the target species. Glossina pallidipes can detect odors from about 50-100 meters. So the traps were spaced at about 200m intervals.

During trapping Acetone dispended from open vials while cow urine from open bottles in to the open bottle of cow urine a piece of tissue paper was included to facilitate odor diffusion. All odors were placed on the ground about $30 \mathrm{~cm}$ up wind of the trap. The trap poles were greased to exclude insect predators like ants (Brightwell et al., 1991).

The different flies cached in each trap were counted, identified and analyzed. The species of tsetse fly was identified based on the characteristic Morphology (Ford et al., 1976; Langridge,1979; Leak et al., 1993) other biting flies were spread according to their Morphological characteristics such as size, color, wing venation. Structure and probes at the genus level (Wall and shearer, 1997).

Sexing was done just by observing the posterior end of the ventral aspect of the abdomen by Microscopic lenses as a result male flies easily identified by enlarged hypopygium in the posterior ventral part of the abdomen. The fly apparent density is the Mean catch in traps deloyed, expressed as the number of fly catch per trap per day (Leak et al., 1987).

\section{RESULTS}

\subsection{Parasitological Survey}

A cross sectional study was conducted on 384 randomly selected cattle to determine the prevalence of bovine trypanosomosis and evaluate associated risk factors. The result of the survey showed that an overall prevalence of $13.54 \%(95 \% \mathrm{CI}=10.10-16.97)$. On PAs basis kure has high prevalence $29.87 \%$ followed by Geza $14.3 \%$ and $13.15 \%, 10.38 \%$ in Bytsemal and Bukkamer respectively. There was no trypanosome positive animal found in Kaysa peasant association.

Table. 1. Prevalence of trypanosomosis on basis of localities

\begin{tabular}{llll}
\hline PA & No. of cattle Examined & Total positive & $\begin{array}{l}\text { Trypanosome } \\
\text { prevalence rate (\%) }\end{array}$ \\
\hline Bukkamer & 77 & 8 & 10.38 \\
Bytsemal & 76 & 10 & 13.15 \\
Geza & 77 & 11 & 14.3 \\
Kaysa & 77 & 0 & 0 \\
Kure & 77 & 23 & 23.87 \\
Total & 384 & 52 & 13.54 \\
\hline
\end{tabular}

3.1.1. Distribution of trypanosome species

The species of trypanosome identified by Buffy coat technique and thin smear showed that T.congolense is the most prevalent with relative prevalence of $63.5 \%$ where as T.vivax $36.5 \%$ but there was no mixed infection.

Table .2. Species of Trypanosome involved in disease process in each peasant associations

\begin{tabular}{|c|c|c|c|c|}
\hline \multirow[t]{2}{*}{ PA } & \multirow{2}{*}{$\begin{array}{l}\text { No. of cattle } \\
\text { Examined }\end{array}$} & \multicolumn{2}{|c|}{$\begin{array}{l}\text { Rate of infections of Trypanasome } \\
\text { species }\end{array}$} & \multirow[t]{2}{*}{ Prevalence $(\%)$} \\
\hline & & T.congallase & T.vivax & \\
\hline Bukkamer & 77 & 4 & 4 & 10.38 \\
\hline Bytsemal & 76 & 6 & 4 & 13.15 \\
\hline Geza & 77 & 8 & 3 & 14.3 \\
\hline Kaysa & 77 & 0 & 0 & 0 \\
\hline Kure & 77 & 15 & 8 & 29.87 \\
\hline Total & 384 & 33 & 19 & 13.54 \\
\hline
\end{tabular}

\subsection{Prevalence of Trypanosome infection in both sexes}

During the present survey, from a total of 384 cattle examined 193 were females and 191 of them were male animals, from the female examined $13.98 \%$ were positive for trypanosome infection while $13.08 \%$ of the male animals were found infected in (table 3). The trypanosome infection in both sexes were almost similar and 
statistically there is no significant difference in the infection rate between male and female animals (chi square $=$ $0.796, \mathrm{p}>0.05)$.

Table 3. Prevalence of Trypanosome infection in both sexes

\begin{tabular}{llll}
\hline Sex & Number of cattle Examined & Number of cattle infected & Prevalence (\%) \\
\hline Female & 193 & 27 & $13.9 \%$ \\
Male & 191 & 25 & 13.08 \\
\hline
\end{tabular}

\subsection{Prevalence of Trypanosome infection in different age groups}

The animals examined were categorized in different age groups as calf (less than 1 year), the young (1-3 years) and adults ( $>3$ years). The prevalence of trypanosomosis on different age groups was $11.5 \%, 18.2 \%$ and $12.2 \%$ in calves, young and adult respectively. Different in infection rate among the different age groups was not statistically significant (chi square $=0.348, \mathrm{p}>0.05$ ).

Table 4. Prevalence of trypanosome in different age

\begin{tabular}{llll}
\hline Age group & Number of cattle examined & Number of cattle infected & Trypanosome prevalence \\
\hline $\begin{array}{l}\text { Calf } \\
\text { (L1 year) }\end{array}$ & 26 & 3 & 11.5 \\
$\begin{array}{l}\text { Young } \\
(1-3 \text { year) }\end{array}$ & 88 & 16 & 18.2 \\
$\begin{array}{l}\text { Adult } \\
(>3 \text { year) }\end{array}$ & 270 & 33 & 12.2 \\
\hline
\end{tabular}

\subsection{Hematological Finding}

To assess the relationship between trypanosome infection and PCV value, PVC Determination Was done by using Hematocrit Method and the Mean PCV of parasitemic and aparasitemic animals were calculated. The mean PCV of parasitemic animals is $25.5 \%$ which fall on the range of anemia and for those aparasitemic animals mean PCV is $30.5 \%$ which is normal PCV value. From a total of $384,24.2 \%$ of animal were found to be anemic and $75.8 \%$ were normal. There is statistically significant difference in the mean PCV value between the infected and noninfected animals (chi square 18.6534, $\mathrm{P}<0.05$ ).

Table 5. PCV evaluation result in each peasant association

\begin{tabular}{lllll}
\hline Pas & $\begin{array}{l}\text { Number of cattle } \\
\text { Examined }\end{array}$ & Mean PVC (\%) & $\begin{array}{l}\text { Cattle with PCV (\%) } \\
<\mathbf{2 6}\end{array}$ & $\begin{array}{l}\text { Cattle with PCV (\%) } \\
\mathbf{2 6}\end{array}$ \\
\hline Bukkamer & 77 & 21.5 & 27.3 & 62.7 \\
Bytsemal & 76 & 22.5 & 21 & 79 \\
Geza & 77 & 30.5 & 22 & 78 \\
Kaysa & 77 & 29.5 & 11.6 & 87.1 \\
Kure & 77 & 24 & 48.1 & 51.9 \\
Total & 384 & 26 & 24.2 & 75.8 \\
\hline
\end{tabular}

\subsection{Entomological Survey}

\subsubsection{Fly Collection}

During entomological survey only one species of tsetse fly was identified this was Glossina pallidipes. A total of 333 tsetse flies were caught and identified at Bystemas (Nare river side) and kure (Pasture land area). The Mean catch of G.Panidipes at Bytsemal (Nare river side) was $15.33 \mathrm{flies/trap/day} \mathrm{where} \mathrm{as} 40.1 \mathrm{flies} /$ trap/ day at kure (pasture land areas) and an overall apparent density of 27.75 flies /trap/day. A total of 350 flies were captured out of which $95.1 \%$ belong to tsetse, $1.4 \%$ tabanus and 3.4\% stomaxy. The tabanid fly group comprises tabanus, Haematopota and chrysops while the Muscid group belongs to stomoxys. From tsetse fly traped female occupied large ratio out of total 333 flies captured $64.5 \%$ flies were females and the $35.5 \%$ comprises male.

Table.6. Tsetse density and species of Glossina

\begin{tabular}{|c|c|c|c|c|c|c|c|c|}
\hline \multirow{3}{*}{$\begin{array}{l}\text { Site } \\
\text { deployment }\end{array}$} & \multirow{3}{*}{$\begin{array}{l}\text { No. } \\
\text { traps }\end{array}$} & \multirow[t]{3}{*}{ of } & \multirow[t]{3}{*}{ Altitude } & \multicolumn{3}{|c|}{ Types of flies } & \multirow{3}{*}{ Total } & \multirow{3}{*}{ Flies /Trap/day } \\
\hline & & & & \multirow[t]{2}{*}{ Species } & \multicolumn{2}{|c|}{ Sex } & & \\
\hline & & & & & $M$ & $\mathrm{~F}$ & & \\
\hline \multirow{3}{*}{$\begin{array}{l}\text { Byssemal } \\
\text { river side) }\end{array}$} & \multirow{3}{*}{6} & & \multirow{3}{*}{1383} & G. pasidipes & 27 & 65 & 92 & 15.33 \\
\hline & & & & Stomoxys & - & - & 6 & 1 \\
\hline & & & & Tabanus & - & - & - & - \\
\hline \multirow{3}{*}{$\begin{array}{l}\text { Kure } \\
\text { land) }\end{array}$} & \multirow[t]{3}{*}{6} & & \multirow[t]{3}{*}{1333} & G.Palidipes & 91 & 150 & 241 & 40.1 \\
\hline & & & & stomoxys & - & - & 6 & 1 \\
\hline & & & & Tapanus & - & - & 5 & 0.83 \\
\hline
\end{tabular}




\section{DISCUSSION}

According to the present parasitological survey a total of 384 local zebu cattle were collected by using simple random sampling method to determine the prevalence of bovine trypanosomosis and associating factors in South Ari woreda of SNNP Region. During the present study an overall prevalence of $13.54 \%$ ( 95\%CI=10.10-16.97) was resulted .The result of the present study (13.54\%) similar to the result of the previous work (12.79\%) by Terfe (1994) in Arbaminch district and with the (12.7\%) by Isak (1990) in North Omo Administration region. The present finding lower than that registered by Shimelise et al., (2006) epidemiology of bovine trypanosmosis in the Ghib valley $40.3 \%$ in late rainy and $19.01 \%$ in dry season, Wondoson (1986) in Bunno $18 \%$ and Abiy (2002) in Goro district $19.01 \%$. This may occur due to the difference in agro ecological of the study area, prophylactic measure and difference in season.

In the present study trypanosome congolonse is predominant species in the study area as compared to the other species of trypanosomes. The predominance of T.congolonse infection in cattle may be due to the high number of serdoms of T.congolonse as compared to T.vivax and the development of better immune response to T.vivax by the infected animal (Leak et al.,1999; Maclennan,1970) The dominancy of T.congolonse (63.5\%) in the present study is in agreement with the previous result of Getachew and Jobre (1996) for tsetse infested areas of Ethiopia (66.1\%), Afework (2001) at Pawe north west Ethiopia (60.9\%), and Terzu (2004) in selected sites of southern region $(63.4 \%)$.

Moreover the result of Tewelde (2004) at Kone (75\%) and village I (93\%) setlment area of Ethiopia, Woldyes and Aboset (1997) at Arbaminch zuria districts (85.2\%) and Rowland et al., (1993) in Ghibe valley, South West of Ethiopia (84\%) had shown higher result of T.congolonse than the present finding. These high ratios of T.congolonse suggest that the major cyclical vector or Glosina species are more efficient transmitors of T.congolonse than T.vivax in East Africa (Langridge, 1976).

Prevalence of bovine trypanosomosis was studied between sex of animals and among 52 Trypanosome positive animals 27 of them were female and 25 were male animals where as there was no statistically significant difference observed during the present study $(\mathrm{P}>0.05)$ in infection rates between male and female animals which consides with the result of Getachew (1993), Tefera (1994), Adane (1995), Who obtained no significant difference in susceptibility between the two sexes. This show that both male and female cattle were equally susceptible to the disease and equal exposure to the vector of the parasite.

The population studied based on their age in to less than one-year-old, 1-3 years and greater than three years old to observe whether they have any influence on the disease prevalence. In the calf group the prevalence was less which happened to be as a result of low exposure to the vector challenge. Conversely in the adult and older age groups of animals the prevalence of trypanosome infection was higher due to the routine contact existing with the tsetse fly in the field, statistically no significant difference was observed $(\mathrm{P}>0.05)$ in the prevalence rate of the disease between age groups. This result supports the result of the previous work by Alekaw (2003) who conclude that there is no significant difference in infection rate between age groups.

In the present study the prevalence of trypanosomosis in different sites of study has different status which may happened due to that some sites of the study area share the border with Mago park which is favorable for tsetse distribution and has different types of wild animals which are important for the disease to act as a host. The prevalence of the disease in study peasant associations were 10.38\% in Bukkamer, 13.5\% in Bytsemal ,14.3 in Geza , $0 \%$ in Kaysa and $23.87 \%$ in kure. The difference was statistically significant $(\mathrm{P}<0.05)$.

During the study period cattle with PCV value less than $26 \%$ was considered anemic (Tewelde, 2004; Rowlands et al., 2001) which is the principal sign for trypanosomosis in the livestock. In the present study, from the total of 384 animals examined 52 of them were parasitemic and there mean PCV value was $25.5 \%$ and 332 of them were aparasitemic with mean PCV value of $30.5 \%$ there were significant difference observed between parasitemic and aparasitemic animals $(\mathrm{P}<0.05)$. This result agrees with the result of the previous work of Alekaw (2003) and Haile (1996) who reported that the mean PCV value of parasitemic animals were significantly lower than that of aparasitemic animals.

The appearance of trypanosome negative animals with mean PCV values of less than $26 \%$ may be due to inadequate of detection method used (Murray et al., 1977) or delayed recovery of anemic situation after resent treatment with trypanosidal drugs or may be due to compound effects of poor nutrition and haematophagus heilmenth infection such as heimoncosis and bunostomosis (Afework et al., 2000). However, PCV values can be affected by many factors other than trypanosomosis. These factors are likely to affect both trypanosomosis positive and negative animals (Van den Bassche and Rowlands; 2001).

On the present entomological survey G.pallidipes was the only species of tsetse detected in the study area with the apparent density of 27.75 flies/trap/day .This result show greater apparent density than earlier report. The report that the Great Rift Valley was infested with G.pallidipes with apparent density of 2.4 flies/trap/day and 0.64 fly/trap/day in wet and dry season (Msangi, 1993). Similarly the mean fly catches of G.pallidipes was 1.42 and for G.fuscipes 0.29 in Ghibe valley (Leak et al., 1983). The variation in flies densities may be due to the area of fly catch which favored trapping of ample amount of flies from vicinities of specially Mago National park which has 
favorable condition for tsetse breeding and reproduction, indicated by (Vreysen et al., 1994) that temperature bellow $15^{\circ} \mathrm{c}$ tsetse flies are in active and about $35^{\circ} \mathrm{c}$ they seek refuge in rot-holes in the trees and animal burrow and deep tissue in the bark, where they remain inactive. Humidity is also important factor both for pupal and adult fly development. Cumulative effect of long rainy season or dry season is thought to influence advance and recession in tsetse population (Leak, 1999).

The presence of wide different types of host animals is essential component of tsetse fly distribution. The distribution and abundance of some species of tsetse flies such as G.morsitans and G.pallidipes which are often known as game tsetse flies are closely related to the number and habits of certain wild animals and also described that the highest densities of certain tsetse fly species are reported from areas with very high densities of wild animals and low human population areas (Leak, 1999).

During the study period, for tsetse flies collected the sex ratio was assessed, Greater ratio of female to male (2:1) was recorded and similar results reported by other workers (Mohammed Ahmed and Dairri, 1987; Msangi, 1999 ) in Somalia and Southern Ethiopia respectively. Leak (1999) reported that in un biased sample female would comprise $70-80 \%$ of the mean populations. The higher population of female may be attributed to the fact that they live longer (mean female fly span being 8 weeks than male about 4 weeks ). So that more female could be caught.

\section{CONCLUSION AND RECOMMENDATIONS}

The study was conducted on the prevalence of bovine trypanosomosis and tsetse identification in South Ari woreda of SNNP Region, the result of the present study revealed that trypanosomosis is the most important problem for agricultural activity and animal production in the study area. From the species of tsetse flies G.pallidipes is considered to be the main vector of the pathogenic trypanosome in the study area and biting flies such as tabanids and musids were also caught and these are also considered very important for the possible mechanical transmission of disease. Among the species T.congolonse was found to be most prevalent trypanosome species in the area. The lower PCV values in parasitemic animals indicated that the typical pathogenesis is observed in the study area. Based on the above conclusion the following recommendations are forwarded:

$>$ Control strategies of trypanosomosis focusing on strong sustainable and Community based approach should be designed and implemented

$>$ Awareness creation about the disease and control methods as well as the risk of trypanocidal drug resistance is required in study area

$>$ Further epidemiological studies should be carried out and appropriate, feasible control of trypanosomosis and/or vector should be implemented.

\section{REFERENCES}

Abiy, M. (2002): Prevalence of bovine trypanosomosis in Goro Woreda, South West Ethiopia, and DVM Thesis. Faculity of Veterinary Medicine Addis Ababa University, Debre Zeit

Adane, M. (1995): Survey on the prevalence of bovine trypanosomosis in and around Bahir Dar. DVM Thesis, AAU, FVM, Debre Zeit, Ethiopia.

Afework, Y., Clausen, P.H., Abebe, G., Tilahun, G. and Mehliz, D. (2000): Appearance of multiple drug resistance trypanosome congolonse population in villages cattle of Metekel district, North West Ethiopia. Acta. Trop. 76, 231-238.

Afework, Y., Cauloson, P. H., Abebe, G., Tilahun, G. and Dieter, M. (2001): Appearance of multiple drug resistance trypanosome population in village cattle of Metekel District, North West Ethiopia. Live stock community and environment. Veterinary Medicine. Copenhagen, Denmark.Pp.1-11.

Alekaw, S. (2004): Epidemiological investigation of mechanically transmitted trypanosomes (Trypanosoma congolonse) of domestic animals in three district bordering Lake Tana ,Ethiopia. MSc thesis, Addis Ababa University Faculty of veterinary medicine, Debre Zeit Ethiopia. Pp. 1-117.

Awoke, K. (2000): Study of trypanosomosis and its vectors in Humbo and Merab Woredas, Eth. Vet. Assc. Journal Vol.4:No.1, Pp.61.

Brightwell. R., Dransfield, RD., and Kyorku, C. (1991): Development of a low coast trap and odor baits for Gllosina pallidipes and G.longpines. Med. Vet. Entimo. In Kenya 5:153-164.

Centeral Statistical Agency (CSA, 2009): Federal Republic of Ethiopia central statistical agency, agricultural sample survey 2008/2009 (2001 E.C.): Report on livestock and livestock characteristics, statistical bulletin 446:39.

Ford. J., Makin , M. J., and Grimble ,R. J. (1976): Trypanosomosis control program for Ethiopia. Minstry of Overseas Development. Great Britain.

Getachew, A. and Jober Y. (1996): Trypanosomosis: A threat for cattle production in Ethiopia Revue. Med .Vet. 147, 897-902.

Hay. S.I., Tucker, C. J., Rogers, D. J. and Packer, M. J. (1996): Remotly sensed surrogates of Metrological Data for the study of Distrebuton and Abundance of arthropode vectors of diseases, Annals Trop.Med. And Par.90, 
$1-19$.

Haile, C. (1996): Bovine trypanosomosis in North Omo: prevalence and assessment of drug efficacy DVM Thesis, Addis Ababa University, Faculity of Veterinary Medicine, Debre Zeit, Ethiopia.

Holmes, P. H. and S. J. Torr (1988): The control of African trypanosomosis in African trypanosomosis current method and future trends Oult Africa.17:54-60.

ILCA/ILRDA (1988): Live stock production in tsetse affected areas of Africa proceeding of a meeting of the Africa Trypanotolerant livestock network, Nairobe, 1987 IUA/ILRDA Pp.473.

Isak E. (1990): Preliminery survey on prevalence of bovine trypanosomosis in three Awurajas of the Northen Omo Administration region DVM Thesis Faculity of veterinary medicine, Addis Ababa University, Debre Zeit Ethiopia.

Itard, J. (1989): African Animal trypanosomosis in: Manual of Tropical Veterinary Parasitology. English Edition CTA/CAB International. walingford UK.

Langridge. W.P. (1976): A Tsetse and Trypanosmiasis survey in Ethiopia. Minstery of overseas development, United Kingdom.

Leak,S. K. A., Woume, K. A., Collaridolle, C., Duffera ,W., Feron, a., Mulingo ,M., Tikubet ,G., Toure, M. and Yangari ,G. (1987): Determination of tsetse challenge and its relationship with trypanosomosis prevalence. In: Livestock production in tsetse infested areas of Africa. Tsetse challenge and its relationship with trypanosomosis CAB international. Walling ford (UK).

Leak, S. G. A., Mulatu, W., Authie, E., d'Ieteren, G., Peregrine, A., Rowlands, G. J., Trail ,J. (1993): Epidemiology of bovine trypanosomosis in the Ghibe valley, South West Ethiopia .Acta Trop. 53,121-134;135-150.

Leak, S. K. A., Woume ,K. A., Collardelle ,C., Duffera ,W., Feron, A., Mulingo ,M. and Yangari, G.(1987): Deterimenation of tsetse challenge and its relationship with trypanosomosis in the Ghibe valley,South West Ethiopia .Acta Trop.53:121-134; 135-150.

Leak.S.G.A. (1999): Tsetse Biology and Ecology: Their role in the epidemiology and control of Trypanosomiasi .CAB International Wallingford (UK).

Maclenna, K.J.R., (1970): The epizitiology of trypanosomosis in West Africa. In: The African Trypanosomosis (ed. Mulligan,H.W.).George Allen and Unwin. London .Pp. 756-765.

Mohamed-Ahimed, M. M., and Dairri, M.F.(1987);Trypanosome infection rate of G.pallidipes durig wet season and dry season in Somalia.Tropical Animal health and prodaction . 19, 11-20.

Moloo S.K. (1993): The distribution of Glosina species and their natural hosts. Insect Sci.Applic.14, 511-527.

Morisun,W.I.,Murray ,M.and Mclnytre W.I.M.(1981):Bovine Trypanosomosis.In: Disease of cattle in the Tropics.Current topics to veterinary Medisine and Animal Sciense ,Vol.6 London :Marinua Nijhaff Publisher.The Hague Netherland.

Msangi, s. (1999): Distribution, Density and infection rates of tsetse flies in selected sites southern rift valley of Ethiopia, MSc thesis .Addis Ababa University Faculty of Veterinary Medicine, Debre Zeit, Ethiopia and Frie University at Berlin.

Murray, M., Murray, P.K. and Mclntyre, W.I.M. (1977): An improved Parasitological technique for the diagnosis of African Trypanosomosis. Trans.R.Soc.Trop.Med.Hyg.71:325-326.

Radostitis, O.M., Gay, C.C., Hinche liff, K.W., Constable, P.D. (2007): African trypanosomiases. A Text book of the disease of Cattle, Horse, Sheep, Pigs and Goats $10^{\text {th }}$ ed. Elsiver London, Pp. 1531-1535.

Rowlands, G.J., Leak, S.G.A., Perigrene, A.S., Nada, S.M., Mulatu, W., d'leteren, G.D.M. (2001): The incidence of new and the prevalence of recurrent trypanosome infection in cattle in South West Ethiopia exposed to high challenge with Drug resistance parasite Acta. Trop. 79, 149-163.

Rowlands, G. J., Mulatu. W., Leak, S. G. A., Nagda, S. M., Wisson, A., d'Iteren , G. D, M. (2000): Use of delta methrine pore on insecticides for the control of cattle trypanosomosis in the presence of high tsetse invasion .Med Vet Entomol.15,87-96.

Rowlands, G. J., Woudyalew, M., Authie, E. J. D., Ieteren, G. D. M., Leak, S. G. A., Nagda, S. M., Peregrine, A. S. and J. M. Mariega (1993): A method for distinguishing new and recurrent trypanosome infections in a field survey of East Africa Zebu cattle in Ethiopia.

Shimelis, D., Alun, K. S., and Getachew A. (2001): Epidemiology of bovine trypanosomosis in the Ghibe Valley settlement area of Nono district, South West Ethiopia, Eth. Vet. Assc. J.12 (1) 21-43.

SIT. (1996): Intergreting the sterile insect control to eradicate tsetse from southern rifet valley of Ethiopia .A Draft Project document a collaborative program between government of Ethiopia and the international atomic energy agensy .Joint FAO/IAEA division.

Takele, A. (1985): Survey of trypanosomosis, its economic impact in Gamo Gofa, DVM Thesis. Addis Ababa University, Faculty of Veterinary Medicine, Debre Zeit, Ethiopia.

Terzu, D. (2004): Seasonal Dynamics of Tsetse and Trypanosomosis in selected sites of Southern Nation, Nationalities and Peoples Regional State (SNNPRS), Ethiopia. MSc Thesis. Addis Ababa University, Faculty of Veterinary Medicine, Debre Zeit, Ethiopia. 
Tewolde N., Abebe,G., Eisler ,M., Mc Dermot .J., Greiner .M., Afework ,Y., Kyule., Munstter Mann, S., Zessin ,K. H., Clausen, P. H.(2004): Application of field methods to assess Isometamidiam resistanse of trypanosomosis in cattle in western Ethiopia. Acta Tropica.9:163-170.

Thrustfield. M., V. (2005): Veterinary epidemiology, $3^{\text {rd }}$ edition. Blackwell Science, Oxford, Pp.233.

Tikubet G. and Gemechu T. (1984): Altitudinal Distribution of tsetse in the Fincha river valley (Western part of Ethiopia) Insect Sci .Appl. 5: 389-395.

Uilenberg, G. (1998): A field Guide for diagnosis,treatment and prevention of African animal Trypanosomosis. Adapted from the original edition by Boyt, W. P. Food and Agriculture organization of United Nations (FAO), Rome Pp.43-135.

Vanden B. P. and Rowlands, G. J. (2001): The relationship between the parasitological prevalence of trypanosome infections in cattle and helped average packed cell volume Acta Trop.78, 168-170.

Vreyesen, M. J. B., Mebrate, A., Menjeta, M., Bancha, B., Woldeyes, G., Musie, K., and Aboset, G. (1999): The distribution and relative abundance of tsetse flies in southern rift valley of Ethiopia: Preliminary survey results. In: Proceedings of the international scientific council for trypanosomosis research and control (ISCTRC), 25 ${ }^{\text {th }}$ meeting held in Mombassa, Kenya .OAU/STRC pubilication no.120.

Walle,R. and Shearer,D. (1997): Veterinary Entimology. Arthropod Ectoparasites of Veterinary Importance. Chapman and Hall, London. Pp, 141-193.

Woldeyes, G. Aboset, G. (1997): Tsetse and trypanosomosis distribution, identification and assessment of socioeconomic viabilities of the new vector control approaches in Arbaminch Zuria Woreda. EVA. Proceedings of the $11^{\text {th }}$ conference. Pp 143-154.

Wondwosen A. (1986): Tsetse and Trypanosomosis inBunno province. DVM Thesis. Faculity of Veterinary Medicine: Addis Ababa Uuniversuty. Debre Zeit.

Woo,P.T.K.(1969):The hematological centrifugation technique for the detection of trypanosomes, Can. J. 47:921923. 